DOI: $10.18276 /$ sip.2017.50/3-09

\title{
Violetta Rutkowska*
}

Uniwersytet Szczeciński

\section{ADMINISTRACJA PUBLICZNA BLIŻEJ OBYWATELA}

\section{Streszczenie}

Współczesność cechuje ciągle zmieniające się otoczenie rynkowe, w którym pojawiają się nowe potrzeby, do których należy się dostosować. Rozwój świadomości konsumenckiej współczesnego klienta wpływa na zmianę oczekiwań obywatela w stosunku do świadczonych czynności administracyjnych w instytucjach państwowych. Realizowane własne przez organy samorządowe zadania zlecone i zadania muszą być wykonywane z należytą starannością, gdyż zadania czynią to w imieniu własnym i na własną odpowiedzialność. Administracja publiczna nie może pozostać obojętna na potrzeby klienta i winna wprowadzać zmiany w koncepcji zarządzania, metodach motywacji, innowacyjnego podejścia do interesanta/klienta, wprowadzaniu nowoczesnych technologii i szeroko pojętej informatyzacji. Istotne jest stworzenie i właściwe wdrożenie standardów obsługi interesanta, które zmienią postrzeganie urzędu oraz zapewnią zadowolenie mieszkańca ze świadczonych usług urzędowych. Powyższe działania warunkują nowatorskie podejście do jakości obsługi klienta, a trudne do skopiowania elementy zarządzania instytucją państwową stworzą wizerunek urzędu przyjaznego i otwartego dla interesanta/klienta, co przyczyni się do wzrostu zadowolenia i zaufania społecznego dla określonej instytucji publicznej.

Słowa kluczowe: klient/interesant, zarządzanie w administracji publicznej, transformacje w urzędach

\footnotetext{
* Adres e-mail: violettarutkowska@o2 lub violetta.rutkowska@um.gorzow.pl
} 


\section{Wprowadzenie}

Przekształcenie gospodarki z centralnie planowanej w rynkową i liberalizacja działalności firm komercyjnych spowodowały ekspansję podmiotów gospodarczych. Wykształciła się silna konkurencja, klient stał się wymagający, nastąpił rozkwit technologii informatycznych. Burzliwe transformacje w firmach doprowadziły do tego, że aby utrzymać się w sektorze, należało dostosować się nowego systemu gospodarczego. Rozwój gospodarki globalnej, członkostwo Polski w Unii Europejskiej, a także wzrost oczekiwań konsumenckich, przyczyniły się do innego postrzegania interesanta w urzędzie. Wobec tego zarządzanie administracją publiczną musiało dostosować się do nowych wymogów i oczekiwań współczesnego obywatela.

W roku 2000 w Nicei Unia Europejska umieściła w Karcie Praw Podstawowych w Artykule 41 „Prawo do dobrej administracji”. Na podstawie wspomnianego aktu normatywnego każdy obywatel Unii Europejskiej ma prawo do bezstronnego, praworządnego i bez zbędnej zwłoki rozpatrzenia sprawy wniesionej do danej instytucji administracji publicznej czy organizacji rządowej. Na instytucjach i organach oraz urzędnikach ciąży natomiast obowiązek rzetelnego i zgodnego z prawem załatwienia sprawy. W przypadku, gdy interesant odniesie szkodę, przysługuje mu roszczenie odszkodowawcze ${ }^{1}$.

Fakt przystąpienia Polski do Unii Europejskiej w roku 2004 wpłynął na konieczność podporządkowania się dyrektywom obowiązującym w krajach członkowskich oraz wprowadzaniu odpowiednich zmian w polskich instytucjach i organach państwowych. Stąd też obligatoryjność dostosowania się realiów i wymogów unijnych. Musiała nastąpić konwergencja, która była nieuchronna (choć to proces trudny do przeprowadzenia).

W latach 2010-2012 Kancelaria Prezesa Rady Ministrów, w ramach projektu „Klient w centrum uwagi w administracji publicznej”, współfinansowanego ze środków Unii Europejskiej z Europejskiego Funduszu Społecznego, przygotowała publikację „Wytyczne do wdrożenia standardów zarządzania satysfakcją Klienta w urzędach administracji rządowej”. Opracowanie zawiera wiedzę niezbędną dla urzędów planujących wdrażanie standardów obsługi klienta w oparciu o idee zarządzania satysfakcją klienta. W dokumencie znajdują się instrukcje i opis dobrych praktyk dotyczące sensu stricte obszarów związanych z interesantem a także „osób wykluczonych lub zagrożonych wykluczeniem administracyjnym lub społecz-

\footnotetext{
1 Szczegółowo opisano w dokumencie „Karta Praw Podstawowych Unii Europejskiej”.
} 
nym. Zaprezentowano działania dotyczące likwidacji barier architektonicznych, usprawnień komunikacyjnych, wprowadzenia udogodnień informatycznych, zwalczania barier językowych, usprawnienia przekazu informacji (bariery informacyjne) ${ }^{2}$ (Kancelaria Prezesa Rady Ministrów, 2017). Na kanwie wyżej wymienionych wymogów zmiany dokonują się w instytucjach administracji publicznej otwartych na współczesność, innowacje i rozwój.

\section{Innowacyjne praktyki obsługi klienta}

Obsługa Klienta urzędu ma charakter niematerialny. Nie posiada żadnych cech namacalnych i dlatego jest szczególnie trudna w realizacji dla interesanta. Ponadto, problemów nastręcza fakt, że usługobiorca z usługodawcą są ze sobą ściśle skorelowani i wszelkie dysonanse wpływają na końcowy efekt świadczonej usługi. Z tego powodu istotnym staje się zwrócenie uwagi na postawę pracowników, którzy swoim zaangażowaniem i współpracą wpływają na jakość obsługi w urzędzie. Istotne jest stworzenie określonych wzorców obsługi interesanta, co jest procesem długotrwałym i wymagającym zaangażowania wszystkich osób zatrudnionych w danej instytucji. Bardzo często wprowadzanie zmian budzi jednak w kadrze urzędniczej bunt, niechęć, a nawet agresję w stosunku do wprowadzanych innowacji. By temu przeciwdziałać, dyrektorzy poszczególnych wydziałów winni organizować grupy dyskusyjne, w których pracownicy czynnie współuczestniczyliby w rozmowach na temat projektów przekształceń, a nawet mieli możność wysuwania swoich propozycji modyfikacji danego pomysłu w celu usprawnienia jakości obsługi interesanta. Proces pozwala zminimalizować błędy mogące pojawić się w trakcie rzeczywistej obsługi klienta, a wówczas na korekty może być zbyt późno.

Wytyczne dotyczące obsługi klienta mają na celu poprawienie poziomu obsługi klienta oraz skorygowanie luk kompetencyjnych urzędników, dlatego ważne jest ciągłe doskonalenie umiejętności kadry pracowniczej. Minimalne zalecenia dotyczą ubioru, wyglądu stanowiska, przestrzegania tajemnicy, rozmowy z interesantem przez telefon, relacji $\mathrm{z}$ klientem oraz radzenia sobie $\mathrm{w}$ zdarzeniach skomplikowanych, czyli:

- dress code - zasady przy doborze ubioru do pracy (np. zakaz noszenia japonek przez kobiety lub krótkich spodenek przez mężczyzn). W szerszym

2 Poszerzone informacje na stronie internetowej ministerstwa - Kancelaria Prezesa Rady Ministrów. 
aspekcie dotyczy zakazu stosowania zbyt mocnego makijażu, intensywnie pachnących perfum itp.;

- sposób obsługi klienta - witanie się z klientem, sposób prowadzenia rozmowy bezpośredniej i przez telefon, korzystanie z e-maila, przekazywanie informacji niekorzystnych dla odbiorcy, obsługa klienta niepełnosprawnego;

- nakaz dbania o stanowisko pracy, które jest nie tylko wizytówką pracownika, lecz również urzędu. Interesant, widząc nieporządek na biurku, może pomyśleć: maja batagan $w$ urzędzie;

- sposób postępowania z agresywnym klientem - pracownicy zazwyczaj nie wiedzą, w jaki sposób mają postępować, gdy klient jest nadpobudliwy. Nie można stosować procedur obowiązujących w kontakcie standardowym. Uśmiech na twarzy urzędnika zwykle jest wskazany w trakcie obsługi typowego interesanta, z pewnością jest jednak nie na miejscu w przypadku obywatela $\mathrm{z}$ brakiem ogłady i może spowodować pogłębienie agresywnego zachowania (Skóbel, 2012).

Wprowadzenie określonych standardów obsługi interesanta jest skutecznym sposobem likwidującym stereotypy urzędnicze. Proponowane rozwiązania sprzyjają poprawie zaufania obywatela do urzędu. Dzięki wprowadzeniu odpowiednich wzorców pracownicy zaczną być traktowani jak profesjonaliści, za pośrednictwem których można skutecznie załatwić sprawę. Zburzony zostanie „mur” uprzedzeń. Instytucja, która wcześniej wydawała się być nieprzychylną, będzie dysponować miłą i fachową kadrą pracowniczą. Pozytywne nastawienie mieszkańców do urzędników poprawi atmosferę w pracy, wskutek czego zwiększy się jej komfort, gdyż środowisko przyjazne, uprzejme, wpływa bezpośrednio na polepszenie jakości i wydajności.

\section{Klient urzędu}

Rozwój mentalności klienckiej oraz rosnące standardy w instytucjach prywatnych sprawiły, że mieszkańcy, udając się do placówki państwowej, oczekują w niej podobnego traktowania przy załatwieniu swojej sprawy urzędowej. Niestety, w urzędach występują jeszcze problemy ze zrozumieniem rzeczywistych potrzeb interesanta, rzetelnym proponowaniem rozwiązań i radzeniem sobie z klientem trudnym. Przeważnie winą obarczany jest obywatel, choć nie do końca jest to prawda; wprawdzie zdarzają się przypadki, że osoba załatwiająca sprawę w urzędzie przybędzie już z nieprzyjaznym 
nastawieniem, jednakże urzędnicy nie powinni generalizować, że istnieją tylko takie zachowania mieszkańców. Urzędnik ma obowiązek zadbać o to, aby mimo frustracji klient urzędu wyszedł z niego zadowolony z miłej, szybkiej i kompetentnej obsługi. Postawa pracownika powinna być w pełni profesjonalna, z zachowaniem sumienności i bezstronności podczas załatwiania sprawy interesanta, nawet tej trudnej, gdyż właśnie takie sytuacje bardzo często wpływają na ogólny wizerunek urzędu.

Zazwyczaj istotne jest pierwsze wrażenie, oddziałujące zarówno na klienta, jak i na pracownika. Urzędnik, pracując zgodnie z etyką urzędniczą i stosując właściwie standardy obsługi, powinien zniwelować nieprzychylne zachowanie obywatela i właściwie załatwić sprawę. Procedura postępowania administracyjnego w urzędzie niekiedy jest czasochłonna. Rzadko która sprawa może być załatwiona „od ręki”, gdyż wymaga obiegu dokumentów w kilku sektorach informacyjnych, czy nawet wysyłki poza granice województwa itp. W związku z tym istotne jest, aby klientowi właściwie wytłumaczyć tok danej procedury administracyjnej i przybliżony czas oczekiwania na załatwienie sprawy. Niestety, ten aspekt budzi wiele napięć i sytuacji konfliktowych u obu stron (klient i urzędnik). Kontakty bezpośrednie „twarzą w twarz" i zawiłość sprawy mogą prowokować powstanie sytuacji trudnej. Czasami może dojść do wyładowania emocji na pracowniku, lecz rezygnacja z dobrych manier, używanie słownictwa obraźliwego czy stosowanie przemocy jest kategorycznie niedopuszczalne i aby nie prowokować eskalacji emocjonalnej sytuacji, pracownik winien znać reguły wyhamowania agresywnego obywatela.

Zgodnie z Kodeksem Postępowania Administracyjnego, każdy obywatel jest uprawniony do sprawiedliwego, jawnego i bez zbędnej zwłoki rozpatrzenia swojej sprawy w urzędzie. Ten ostatni ma obowiązek zaoferować wszechstronną pomoc stronie w przypadku, gdy dany urzędnik czy wydział nie zajmuje się określonym problemem i jest zobligowany sprawę przekazać według właściwości.

Interesant ma prawo do „dobrej administracji”, czyli informacji o sprawie, w której ma interes prawny, przeglądania swoich akt i zadawania pytań, składania wyjaśnień w danym postępowaniu, wnoszenia skarg i wniosków, odwołania się od wydanej przez urząd decyzji. Przedstawione działanie ma na celu uniknięcie szkody. Dzieje się to na każdym etapie sprawy, czyli od wszczęcia do wydania prawomocnej decyzji. W przypadku zaistnienia niezgodnego z prawem postępowania urzędniczego i powstania szkody (udzielenia nieprawidłowej, fragmentarycznej czy wadliwej informacji), to poszkodowany ma prawo do wynagrodzenia tej straty (ubieganie się o roszczenie odszkodowawcze), gdyż obywatel nie powinien ponosić skutków wadliwości postępowania urzędniczego. 
Konkludując, należy pamiętać, że człowiek jest podmiotem, a nie przedmiotem i to dla niego jest administracja publiczna, nie zaś odwrotnie, choć niekiedy występują jeszcze wspomniane stereotypy. Urzędy, które ewoluują i zaczynają postrzegać interesanta jako klucz do rozwiązania swoich problemów i poprawienia image'u, starają się dostosowywać do wyjątkowych potrzeb człowieka, to znaczy nie wymuszają na mieszkańcu dostosowania się do specyficznych wymogów administracji. Stanie się to globalnym osiągnięciem dopiero, gdy powstaną dodatkowo korzystne regulacje prawne, normy, dyrektywy itp.

\section{Racjonalizatorska koncepcja rozwoju urzędników}

Kapitał ludzki stanowi najważniejszy element kapitału intelektualnego. Sam system organizacji i zarządzania, choćby najbardziej profesjonalny - bez ludzi, którzy go tworzą, utrzymują i obsługują - nie ma żadnej wartości (Dudycz, 2005, s. 18). Można powiedzieć, że rozwój kadr stanowi zasadniczą strategię przeżycia i rozwoju organizacji. Rozwój pracowników powinien zatem być podstawową wartością zarówno dla organizacji, jak i dla niego samego (Listwan, 1993, s. 73).

Nowatorska wizja poszerzenia kompetencji i umiejętności pracowniczych sprowadza się do pogłębiania wiedzy urzędnika przy pracy na obecnym lub przyszłym stanowisku. Istotną cechą kadry pracowniczej jest zdolność do tworzenia innowacji czy projektowania i wdrażania długookresowych modyfikacji w postępie przebudowy instytucji publicznej.

Dodatkowym atrybutem dla urzędów jest zatrudnianie kadry wykształconej, która dzięki posiadanej już wiedzy i umiejętnościom, będzie potrafiła je skutecznie wykorzystać, a ewentualne systematyczne szkolenia zwiększą jej fachowość, kunszt i swobodę na stanowisku pracy.

Kapitał intelektualny to inaczej materiał intelektualny, który został sformalizowany, ujęty i zmuszony do działania w celu stworzenia majątku o wyższej wartości. Kapitału intelektualnego, w odróżnieniu od kapitału finansowego czy rzeczowego, nie ujmuje się w sprawozdaniach finansowych. Ma związek z intelektem pracowników, regulacjami pomiędzy nimi i ich otoczeniem oraz strukturą, w jakiej funkcjonują (Leśniewski, 2011, s. 14-15).

Jest wiele aspektów wpływających na złe postrzeganie urzędników, np. brak kultury osobistej i szacunku dla drugiej osoby, prywatne rozmowy telefoniczne przy kliencie, odbieranie połączeń służbowych czy forma pierwszego kontaktu itp. 
Inną bolączką mieszkańców jest tzw. spychologia, gdy urzędnik nie ma wiedzy merytorycznej z danej dziedziny lub kompetencji i odsyła interesanta w niewłaściwe miejsce, aby po prostu „pozbyć” się problemu. Spowodowane jest to ograniczonymi kwalifikacjami związanymi z brakiem wiedzy szerszej niż ta, którą się posługuje na swoim stanowisku pracy. Rzadko który urzędnik potrafi jasno i w formie przystępnej dla interesanta wyjaśnić zagadnienie oraz pokierować sprawą tak, aby klient zadowolony wyszedł z urzędu. Dlatego istotnym staje się fakt ustawicznego dokształcania urzędników i ich samokształcenia w wiedzy zarówno tej merytorycznej, związanej z aktami normatywnymi i procedurami administracyjnymi, jak i obsługą klienta, czyli szkoleń: informacyjnych i informatycznych, wizerunkowych, radzenia sobie z trudnym klientem lub nawet warsztaty czy spotkania z psychologiem. Wówczas kompetentnie przygotowany pracownik idealnie wkomponuje się w kompleksową obsługę interesanta (sala obsługi klienta), w której to obywatel podchodzi do właściwego stanowiska obsługowego i załatwia sprawę. W przypadku zawiłości sprawy zostaje przekierowany do innego pracownika, gdzie będzie rzetelnie obsłużony. Wówczas widać będzie, że urząd i urzędnicy wykazują pełen profesjonalizm w czynnościach, a ich działania nie będą chaotyczne ani ułomne.

Literatura przedmiotu wskazuje, że nadrzędny zasób strategiczny stanowią pracownicy instytucji i, w zależności od przyjętej koncepcji zarządzania zasobami ludzkimi, można uzyskać przewagę konkurencyjną lub ją stracić. Istotę przewagi konkurencyjnej stanowią jednak tylko tak zwane kluczowe kompetencje, zatem kombinacja unikalnych umiejętności pozwalających przedsiębiorstwu uzyskać długookresowe efekty synergiczne, a w konsekwencji możliwość dywersyfikacji działalności w kierunku obszarów pozornie niezwiązanych z jego podstawową działalnością lub nawet uznawanych za mało atrakcyjne (Rosińska, 2007, s. 2).

Reasumując, można stwierdzić, że zarządzanie zasobami ludzkimi postrzega się jako cenne źródło sukcesów firmy i traktuje je nie jako koszty zmienne, lecz raczej jako majątek trwały, stąd też należy im zapewnić możliwości pełnego rozwoju posiadanych zdolności i jak najlepszych przywódców (Armstrong, 1996, s. 9), którzy pokierują właściwie rozwojem intelektualnym urzędników (plan rozwoju kariery urzędniczej), dając możliwość wykreowania idealnego urzędnika XXI wieku. 


\section{System motywacji pracownika}

Natura człowieka jest bardzo skomplikowana, toteż nie ma idealnego narzędzia motywującego pracownika. Motywację można określić jako niezaspokojone pragnienie. Nie da się oddzielić pragnienia od motywacji, zawsze są one jednakowo silne. Wyróżnić można trzy poziomy motywacji:

- podporządkowanie: pracownik wykonuje to, co każe przełożony, tak jakby sam nie potrafił myśleć i nie miał żadnych uzdolnień,

- identyfikacja celu: rodzi pragnienie osiągnięcia celu. Aby móc osiągnąć drugi poziom, trzeba wyraźnie zakomunikować pracownikowi korzyści płynące $\mathrm{z}$ rezultatu,

- zaangażowanie: na tym poziomie pracownik uważa cel za własny. Aby osiągnąć trzeci poziom, pracownik musi pojąć, że jest jedyną osobą, której powierzono dane zadanie i poczuć, że dobra praca leży w jego interesie (Mazur, 2013, s. 157).

Aktualnie motywator finansowy nie jest priorytetem. Obecnie miejsce zatrudnienia staje się płaszczyzną do realizacji swoich zamiłowań czy inicjowania więzi z pracownikami i dlatego współcześnie stosuje się pozafinansowe instrumenty motywacyjne. Należy pamiętać, że praca zabezpiecza podstawowe potrzeby bytowe i dlatego stworzenie odpowiedniego systemu motywowania to kluczowy człon zarządzania kadrą pracowniczą. Zwiększa się wówczas zaangażowanie pracowników, poprawia atmosfera w zespole oraz wzmacnia się więź z pracodawcą. Specjaliści twierdzą, że nagradzanie za rezultaty przynosi bardziej pozytywne działanie niż same obligatoryjne podwyżki lub stosowanie strategii „kija i marchewki”. Trudność polega na znalezieniu takiego rozwiązania, kiedy pracownik zaangażuje swój potencjał umysłowy, wykaże się kreatywnością i pomysłowością w wykonywaniu powierzonych mu czynności.

\section{System oceny urzędnika}

Współczesny urzędnik powinien sobie zdawać sprawę, że kompetencje merytoryczne nie wystarczą, by prezentować profesjonalny wizerunek. Motywacja i zaangażowanie w pracę są u pracownika wyjątkowo cenne. Wielokrotnie zauważalny jest problem, że urzędniczka z wieloletnim stażem pracy wykazuje mniejsze zaangażowanie i determinację w pracy zawodowej, niż młody pracownik lub stażysta. 
Młodemu pracownikowi zależy na dobrze wykonanej pracy i swoje braki w wiedzy merytorycznej uzupełnia większym zaangażowaniem, chęcią wprowadzania innowacji czy niesieniem pomocy zagubionemu interesantowi. Dlatego korzystniejszą ocenę interesant przypisze młodej osobie, gdyż zainteresowanie $\mathrm{i}$ indywidualne podejście (mimo mniejszej wiedzy) jest lepiej postrzegane przy kontakcie z klientem, niż większa wiedza połączona $\mathrm{z}$ aroganckim i lekceważącym stosunkiem (co jest typowym zachowaniem wśród wieloletnich pracowników urzędu). Obsługa interesanta powinna zatem spełniać określone normy i standardy. Fakt, że jest to problem ważki, potwierdza działanie Kancelarii Prezesa Rady Ministrów, który w artykule „Monitorowanie jakości obsługi klienta - Dobre praktyki” (Kancelaria Prezesa Rady Ministrów i in., 2017) oraz w publikacji „Pomiar jako środek do doskonalenia” (Kancelaria Prezesa Rady Ministrów i in., 2017) ukazuje niezbędność pilotowania przez państwo kształtowania systemu obsługi jakości klienta w urzędach administracji publicznej.

Przestrzeganie wzorców obsługi interesanta musi być okresowo weryfikowane, gdyż nowe zwyczaje w obsłudze klienta wymagają od urzędnika zachowania etyki i etykiety. Kontrolowane są obszary z zakresu: wiedzy merytorycznej na danym stanowisku pracy (urzędnik zobowiązany jest znać akty normatywne, które są podstawą jego zatrudnienia w wydziale), wiedzy i umiejętności profesjonalnej obsługi w urzędzie, efektywnej i poprawnej komunikacji, kreowania postawy asertywnej obsługi klienta czy pozytywnego nastawienia do obywatela, obsługi ,trudnego" interesanta, radzenia sobie z krytyką usługobiorcy oraz właściwego zachowania w sytuacji trudnej związanej z merytorycznym problemem konsumenta, przyjmowania uzasadnionej reklamacji, a także ocena umiejętności z zakresu: postrzegania sytuacji z perspektywy klienta, rozpoznawania jego potrzeb i działania po wykonaniu obsługi interesanta.

\section{Podsumowanie}

Współczesne organizacje i instytucje publiczne zaczynają dbać o kreowanie własnego wizerunku, gdyż przyczynia się to do wzrostu zaufania obywatela do istniejącej władzy publicznej. Jest to trudne dla urzędów, ponieważ wykonują usługi o charakterze niematerialnym. Uzyskanie ,zysku”, tak zwanej przewagi konkurencyjnej/wizerunkowej, dokonuje się na płaszczycie niemożliwej do oszacowania miernikami stosowanymi w prywatnych podmiotach gospodarczych, jak to się dzieje 
np. w produkcji lub sprzedaży towaru czy usług komercyjnych, bo korzyść z tego tytułu wyrażona jest w pieniądzu. Dlatego administracja publiczna dokonuje tego typu działań na innych płaszczyznach, np. uczestnictwo w imprezach masowych lub ich organizowanie, dni drzwi otwartych, konsultacje społeczne, przekazywanie informacji o podejmowanych działaniach poprzez media, internet czy też portale społecznościowe. Są to kluczowe narzędzia do realizacji tego typu idei.

Należy pamiętać, że klient urzędu XXI wieku zaczyna inaczej postrzegać obsługę i oczekuje pewnych standardów obowiązujących w firmach prywatnych. Może się okazać, że mimo profesjonalnie przeprowadzonych zmian, pojawia się problem wizerunkowy. Klient/interesant przychodzi do urzędu z potrzebą konsumencką, istotne znaczenie ma sposób załatwienia jego problemu. Od tego, czy sprawa zostanie załatwiona kompetentnie i bez zbędnej zwłoki, zależy zadowolenie tego mieszkańca. Osiągnięta w ten sposób korzyść wpłynie bezsprzecznie na satysfakcję z jakości obsługi w dłuższym i krótszym przedziale czasowym. Zasadnicze jest zachowanie osoby pierwszego kontaktu; jej postawa wobec konsumenta, wiedza i kompetencje urzędnicze znacząco wpływają na ocenę urzędu przez obywatela. Nawet najtrudniejsze i bardzo zawiłe sprawy można szybko rozwiązać. W przypadku pojawienia się agresywnego klienta właściwe podejście pracownika natychmiast rozstrzyga problem i wycisza otoczenie.

Należy pamiętać, że w świadomości potencjalnego konsumenta istnieje pewien utarty stereotyp, który niejednokrotnie ma potwierdzenie w rzeczywistości. Dlatego należy burzyć „stare układy” i „powiązania”, które są skostniałe i hamują rozwój administracji publicznej. Zmiany i rewolucje są trudne, lecz w perspektywie długoterminowej korzystne dla wszystkich obywateli i instytucji. Zastosowanie proponowanych zmian ewidentnie wpływa na pozytywny wizerunek i dobrą reputację, dlatego urzędy winny się transformować.

\section{Literatura}

Armstrong, M. (1996). Zarządzanie zasobami ludzkimi. Strategia i działanie. Kraków: Wydawnictwo Profesjonalnej Szkoły Biznesu.

Bugdol, M. (2008). Zarzadzanie jakościa w urzędach administracji publicznej - teoria i praktyka. Warszawa: Difin.

Dębicki, M. (2001). Urzędnik XXI wieku. W: B. Kudrycka (red.), Rozwój kadr administracji publicznej, 7-25. Białystok: Wyższa Szkoła Administracji Publicznej w Białymstoku.

Dudycz, T. (2005). Zarzadzanie wartościa przedsiębiorstwa. Warszawa: PWE. 
Kancelaria Prezesa Rady Ministrów - BIP (2017). Karta Praw podstawowych Unii Europejskiej. Pobrane z: https:/www.mpips.gov.pl/spoleczne-prawa-czlowieka---niowa/ prawa-czlowieka-w-unii-europejskiej/karta-praw-podstawowych-unii-europejskiej.

Kancelaria Prezesa Rady Ministrów (2017). Monitorowanie jakości obsługi klienta. Pobrane z: https://dsc.kprm.gov.pl/monitorowanie-jakosci-obslugi-klienta-1.

Kancelaria Prezesa Rady Ministrów (2017). Pomiar jako środek do doskonalenia. Poprawa funkcjonowania sektora publicznego dzięki wykorzystaniu informacji na temat poziomu satysfakcji klienta-obywatel. Pobrane z: https://dsc.kprm.gov.pl/sites/default/files/ pliki/pomiar_jako_srodek_do_doskonalenia_2.pdf.

Kancelaria Prezesa Rady Ministrów (2012). Wytyczne do wdrożenia standardów zarzadzania satysfakcja klienta $w$ urzędach administracji rzadowej. Pobrane z: https://dsc. kprm.gov.pl/sites/default/files/pliki/monitorowanie_wytyczne.pdf.

Leśniewski, M.A. (2011). Kapitał intelektualny w rozwoju organizacji. Wybrane aspekty analizy problemu. Studia i Materiały Miscellanea Oeconomicae, 2. Ludzie, zarzadzanie, gospodarka, 11-23.

Listwan, T. (1993). Kształcenie kadry menedżerskiej firmy. Wrocław: Wydawnictwo „Kadry".

Mazur, M. (2013). Motywowanie Pracowników jako istotny element zarządzania organizacji. Nauki Społeczne Social Sciences, 2 (8), 156-182.

Miasto stołeczne Warszawa (2016). Standardy obstugi. Pobrane z: http://www.um.warszawa. $\mathrm{pl} /$ zalatw-sprawe-w-urzedzie/artykuly-sprawy-urzedowe/standardy-obslugi-klienta.

Rosińska, M. (2007). Kapitał ludzki podstawą budowania przewagi konkurencyjnej współczesnych przedsiębiorstw. W: J. Bogdanienko, M. Kuzel, I. Sobczak (red.), Uwarunkowania budowania konkurencyjności przedsiębiorstw $w$ otoczeniu globalnym. Toruń: Wydawnictwo Adam Marszałek.

Skóbel, B. (2012). Standardy Obstugi Klienta w urzędzie. Pobrane z: http://wartowiedziec. org/index.php/start/felietony/8116-standardy-obsugi-klienta-w-urzdzie.

Sobolewska-Noel, J. (2013). Rynkowe trendy i koncepcje w dziedzinie zarządzania w administracji publicznej jako odpowiedź na potrzeby reform współczesnej administracji publicznej. Zeszyty Naukowe Instytutu Spraw Publicznych UJ. Zarządzanie publiczne, 1 (21), 25-41.

Urząd Miasta Mława (2011). Standardy obstugi klienta-załącznik do zasady komunikacji wewnętrznej UMM. Pobrane z: http://www.mlawa.pl/g2/oryginal/bip/690/0000000000814506.pdf.

Urząd Miasta Warszawa. Aktualności sprawy urzędowe. Standardy obstugi klienta. Pobrane z: http://www.um.warszawa.pl/sites/default/files/aktualnosci_sprawy_urzedowe/standardy_obslugi_klienta.pdf. 


\title{
PUBLIC ADMINISTRATION CLOSER TO THE CITIZEN
}

\begin{abstract}
Contemporary times are characterized by the constantly changing market environment, in which there are new needs to which one must adapt oneself. The development of the contemporary client's consumer awareness leads to change of a citizens' expectations to the performance of administrative services by state government agencies. Assignments performed as delegated and own by local government bodies must be completed with due diligence through the fact that they carry out their tasks on their own behalf and under their own responsibility. Public administration may not remain indifferent to clients' needs and should introduce changes to a concept of management, motivation methods, innovative approach towards a petitioner/client, implementation of modern technologies and broadly understood computerization. It is necessary to establish and properly implement customer service standards, which can affect the perception of administrative organs and ensure residents' satisfaction regarding the administrative services provided. These actions have an impact on innovative approach to customer service quality and the difficult to reproduce elements of management of a state institution will create an image of a citizen-friendly and open administrative body, which will contribute to the increase of people's satisfaction and trust in a specific public institution.
\end{abstract}

Translated by Katarzyna Demidowicz

Keywords: client/petitioner, public administration management, transformations of government offices

JEL Codes: R1, R5 